\title{
KONSEPTUALISASI DAN PELUANG CYBER NOTARY DALAM HUKUM
}

\author{
Cyndiarnis Cahyaning Putri, Abdul Rachmad Budiono
}

Program Studi Magister Kenotariatan, Fakultas Hukum, Universitas Brawijaya

Jl. M.T. Haryono 169 Ketawanggede. Lowokwaru, Kota Malang

Email: cndy_13@hotmail.com

\begin{abstract}
: this paper aims to reveal the conceptualization and opportunity of the concept of the cyber notary as one of the other notary authorities as stated in the explanation of Article 15 Section (3) of Law Number 2 of 2014 concerning Amendments to Law Number 30 of 2004 concerning Position of Notary Public (UUJN). This paper is a normative study using the statute approach and conceptual approach. The concept of a cyber notary can be interpreted as a method for a notary in carrying out their duties and authorities by using electronic equipment (cyber), but their authority has limitations for the authority of certification of transactions conducted electronically. Opportunities for the concept of a cyber notary can be reviewed in the drafting of the results of the General Meeting of Shareholders based on Article 77 of Law Number 40 of 2007 concerning Limited Liability Companies and storage of the Notary protocol in electronic form. The application of cyber notary is still constrained by UUJN which has not yet opened up opportunities for deed making through electronic media.
\end{abstract}

Keywords: cyber notary, conceptualization, opportunity

\begin{abstract}
Abstrak: tulisan ini bertujuan untuk mengungkapkan konseptualisasi dan peluang konsep cyber notary sebagai salah satu kewenangan notaris lainnya sebagaimana tercantum dalam penjelasan Pasal 15 ayat (3) Undang-Undang Nomor 2 Tahun 2014 tentang Perubahan Atas Undang-Undang Nomor 30 Tahun 2004 tentang Jabatan Notaris (UUJN). Tulisan ini merupakan tulisan normatif dengan menggunakan pendekatan perundang-undangan dan pendekatan konseptual. Konsep cyber notary dapat dimaknai sebagai metode bagi notaris dalam menjalankan tugas dan kewenangan jabatannya dengan menggunakan pranata elektronik (cyber), namun kewenangan tersebut berlaku limitatif terhadap kewenangan sertifikasi transaksi yang dilakukan secara elektronik. Peluang konsep cyber notary dapat ditinjau dalam pembuatan akta hasil Rapat Umum Pemegang Saham yang didasari oleh Pasal 77 Undang-Undang Nomor 40 Tahun 2007 tentang Perseroan Terbatas dan penyimpanan protokol Notaris dalam bentuk elektronik. Penerapan cyber notary masih terkendala oleh UUJN yang belum membuka peluang terhadap pembuatan akta melalui media elektronik.
\end{abstract}

Kata Kunci: cyber notary, konseptualisasi, peluang

\section{PENDAHULUAN}

Keberadaan dunia maya sering disebut dengan cyberspace yang dapat diakses dengan mudah melalui internet, menimbulkan batasan-batasan dimensi ruang menjadi hampir tidak tampak lagi. Perkembangan teknologi ini juga berimplikasi dalam bidang kenotariatan, yang kemudian muncul sebuah gagasan mengenai cyber notary.

Perkembangan dan kemajuan teknologi informasi demikian pesat telah menyebabkan perubahan kegiatan kehidupan manusia dalam berbagai bidang yang secara langsung telah mempengaruhi lahirnya perbuatan atau tindakan hukum baru. Lantas peluang dan tantangan bagi Notaris pada era globalisasi ialah munculnya tuntutan bagi Notaris agar tidak hanya bekerja secara manual tetapi juga mampu memanfaatkan informasi yang berbasis teknologi (Nurita, 2012:3)

Konsep cyber notary pertama kali 
terdapat dalam Undang-Undang Nomor 2 Tahun 2014 tentang Perubahan Atas Undang-Undang Nomor 30 Tahun 2004 tentang Jabatan Notaris (selanjutnya disebut "UU Jabatan Notaris 2014") yang mengatur tentang kewenangan-kewenangan notaris sebagaimana tercantum dalam Pasal 15 UU Jabatan Notaris 2014. Pasal 15 ayat (3) UU Jabatan Notaris 2014 disebutkan mengenai kewenangan notaris, salah satunya ialah frasa "... kewenangan lainnya yang diatur dalam peraturan perundang-undangan". Penjelasan mengenai apa yang dimaksud dengan "kewenangan lainnya" terdapat dalam penjelasan Pasal 15 ayat (3) yang berbunyi: "Yang dimaksud dengan kewenangan lain yang diatur dalam peraturan perundang-undangan", antara lain, kewenangan mensertifikasi transaksi yang dilakukan secara elektronik (cyber notary), membuat akta ikrar wakaf, dan hipotek pesawat terbang." Kewenangan tersebut hanya terdapat pada satu pasal, dan terletak pada bagian penjelasan pasal, yakni dalam Penjelasan Pasal 15 ayat (3). Kedudukan penjelasan dalam suatu undangundang pun tidak termasuk kepada materi batang tubuh suatu undang-undang.

Kebutuhan masyarakat terhadap akta autentik semakin meningkat seiring dengan meningkatnya perkembangan ekonomi. Dilihat dari perspektif perbuatan hukum, terdapat perbuatan hukum yang memiliki syarat bahwa harus perbuatan hukum tersebut harus dituangkan ke dalam bentuk akta autentik. Kebutuhan masyarakat terhadap hukum cenderung selalu berkembang dan dinamis selaras dengan perkembangan informasi dan teknologi. Oleh karenanya hukum seyogyanya harus selalu turut berkembang mengikuti perkembangan masyarakat, bukan menjadi sebuah hambatan dalam perkembangan masyarakat. Peningkatan aktivitas sosial dan ekonomi dengan konstelasi masyarakat dunia telah memasuki suatu masyarakat yang berorientasi kepada informasi (Budhijanto, 2010:1).

Pranata cyber notary merupakan suatu terobosan hukum yang dilakukan guna memenuhi kebutuhan hukum dalam masyarakat, khususnya terhadap Notaris dalam era globalisasi, namun pranata cyber notary tersebut masih memiliki kekurangan baik dalam hal pemaknaan hingga konseptualisasinya dalam pembuatan Akta melalui pranata cyber notary. Namun dalam pengaturannya, konsep cyber notary belum dapat dilaksanakan dengan efektif dan efisien dikarenakan adanya kekosongan hukum antara makna dan peraturan pelaksanaan daripada cyber notary itu sendiri. Sehingga di sini terlihat bahwasanya pranata cyber notary telah diatur namun memiliki kekosongan hukum (rechtsvacuum) dalam perspektif pemaknaannya. Dalam kekosongan hukum tentu menimbulkan akibat terhadap pranata cyber notary, sehingga menimbulkan kesukaran terhadap dilangsungkannya salah satu kewenangan notaris.

Pemaknaan tersebut dapat menimbulkan implikasi bahwasanya dalam perbuatan hukum Notaris manakah yang dapat diterapkan melalui pranata cyber notary. Konsep cyber notary sendiri tidak terdapat batasan pemaknaan, sehingga dalam hal ini ketentuan yang termaktub dalam UU Jabatan Notaris terhadap cyber notary mengakibatkan tidak dapat dilaksanakan. Namun, apabila mengacu pada peraturan perundang-undangan lainnya, misalnya pada ketentuan mengenai Rapat Umum Pemegang Saham (selanjutnya disebut "RUPS"), yang mana hasil risalah RUPS merupakan akta Notaris berupa akta pejabat (relaas acten).

Pelaksanaan RUPS melalui media telekonferensi tercantum pada pasal 77 ayat (1) Undang-Undang Nomor 40 Tahun 2007 tentang Perseroan Terbatas yaitu: "Selain penyelenggaraan RUPS sebagaimana dimaksud dalam Pasal 76, RUPS dapat juga dilakukan melalui media telekonferensi, video konferensi, atau sarana media elektronik lainnya yang memungkinkan semua peserta RUPS saling melihat dan mendengar secara langsung serta berpartisipasi dalam rapat."

Pada Undang-Undang tersebut 
dilakukan perubahan atas ketentuan yang menyangkut penyelenggaraan RUPS dengan memanfaatkan perkembangan teknologi. Dengan demikian, penyelenggaraan RUPS dapat dilakukan melalui media elektronik seperti telekonferensi, video konferensi, atau sarana media elektronik lainnya. Ketentuan tersebut dapat dikatakan merupakan salah satu terobosan hukum yang memanfaatkan kemajuan teknologi dalam pengimplementasiannya.

Pranata cyber notary merupakan suatu terobosan hukum yang dilakukan guna memenuhi kebutuhan hukum dalam masyarakat, khususnya terhadap Notaris dalam era globalisasi, namun pranata cyber notary tersebut masih memiliki kekurangan baik dalam hal pemaknaan hingga konseptualisasi serta peluang dalam pembuatan Akta melalui pranata cyber notary. Berdasarkan kepada kompleksitas permasalahan yang terjadi dalam pranata cyber notary, maka tulisan ini akan mengkaji konseptualisasi cyber notary berdasarkan sistem hukum Indonesia serta peluang penerapan cyber notary dalam sistem hukum di Indonesia.

\section{METODE}

Tulisan ini merupakan kajian yuridis normatif, dengan menggunakan pendekatan perundang-undangan (statute approach) dan pendekatan konseptual (conceptual approach). Pendekatan perundang-undangan digunakan untuk menganalisis berbagai peraturan perundang-undangan yang terkait dengan cyber notary sedangkan pendekatan koseptual digunakan untuk menganalisis dan mengkaji secara komprehensif mengenai konsep cyber notary.

Jenis dan sumber bahan hukum dalam kajian ini meliputi bahan hukum primer, bahan hukum sekunder, dan bahan hukum tersier. Bahan hukum primer dalam kajian ini berupa peraturan perundang-undangan yang terkait dengan kewenangan Notaris dalam mebuat akta Notaris melalui pranata cyber notary, diantaranya adalah: a) Kitab Undang-undang Hukum Perdata; b) Undang-
Undang Nomor 30 Tahun 2004 tentang Jabatan Notaris; c) Undang-Undang Nomor 2 Tahun 2014 tentang Perubahan Atas Undang-Undang Nomor 30 Tahun 2004 tentang Jabatan Notaris; d) Undang-Undang Nomor 40 Tahun 2007 tentang Perseroan Terbatas.

Bahan hukum sekunder pada kajian ini berupa bahan pustaka, jurnal, jurnal dan artikel online, literatur asing, serta pendapat para ahli berkenaan dengan kewenangan Notaris dalam membuat akta Notaris melalui pranata cyber notary. Sedangkan bahan hukum tersier mencakup bahan-bahan yang memberikan petunjuk terhadap bahan hukum primer dan sekunder, seperti Kamus Hukum, dan lain-lain.

\section{HASIL DAN PEMBAHASAN}

Konseptualisasi Cyber Notary Berdasarkan Sistem Hukum di Indonesia

Sejarah perkembangan cyber notary pertama kali dimunculkan pada tahun 1989 , dalam Trade Electronics Data Interchange System Legal Workshop yang diselenggarakan oleh Uni Eropa, frasa "electronic notary" pertama kali diprakarsai oleh delegasi dari Perancis, yang memiliki pengertian: "Various industry associations and related peak bodies could act as an "electronic notary" to provide an independent record of electronic transactions between parties, i.e., when company A electronically transmits trade documents to company $B$, and vice versa." (Smith, 2006:1).

Pendefinisian frasa "cyber notary" kemudian dikemukakan di Amerika Serikat oleh the Information Security Committee of the American Bar Association pada tahun 1994, yang berbunyi: "The committee envisaged that this proposed new legal professional would be similar to that of a notary public but in the case of the Cyber notary his/her function would involve electronic documents as opposed to physical documents. This would be an office, which would be readily identifiable and recognized 
in every country throughout the world: i.e., as a legal professional who has been placed in a position of a heightened level of trust. They would have the responsibility to undertake certain types of legal transactions than that of the public officer generally referred to in the United States as a notary." (Smith, 2006:1).

Pendefinisian electronic notary dan cyber notary pada dasarnya memiliki persamaan, bahwa media yang dipergunakan dalam perbuatan tersebut merupakan media elektronik (tidak berwujud) sebagai substitusi daripada dokumen kertas (berwujud) pada umumnya. Namun gagasan cyber notary oleh the Information Security Committee of the American Bar Association memberikan cakupan definisi lebih spesifik yakni cyber notary merupakan profesi hukum baru yang serupa dengan Notaris publik, namun dalam cyber notary memiliki fungsi yang melibatkan dokumen elektronik.

Konsep cyber notary di Indonesia pertama kali termaktub dalam Undang-Undang Nomor 2 Tahun 2014 tentang Perubahan atas Undang-Undang Nomor 30 Tahun 2004 tentang Jabatan Notaris (selanjutnya disebut "UUJN 2014") yang disebutkan mengenai kewenangan-kewenangan dari Notaris sebagaimana tercantum dalam pasal 15 UUJN 2014. Dalam Pasal 15 ayat (3) UUJN 2014 disebutkan mengenai kewenangan notaris, salah satunya ialah terdapat frasa "...kewenangan lainnya yang diatur dalam peraturan perundang-undangan”.

Penjelasan mengenai apa yang dimaksud dengan "kewenangan lainnya" terdapat dalam penjelasan Pasal 15 ayat (3) yang berbunyi: "Yang dimaksud dengan "kewenangan lain yang diatur dalam peraturan perundangundangan", antara lain, kewenangan mensertifikasi transaksi yang dilakukan secara elektronik (cyber notary), membuat Akta ikrar wakaf, dan hipotek pesawat terbang."

Namun demikian, dalam UU Jabatan Notaris, masih belum terdapat definisi normatif dari cyber notary. Sehingga dalam hal ini, konsep cyber notary dapat merujuk kepada pengertian dari para ahli. Konsep cyber notary menurut R.A. Emma Nurita, yaitu: "Konsep cyber notary untuk sementara dapat dimaknai sebagai notaris yang menjalankan tugas dan kewenangan jabatannya dengan berbasis teknologi informasi yang berkaitan dengan tugas dan fungsi notaris, khususnya dalam pembuatan akta."(Nurita, 2012:4).

Edmon Makarim berpendapat bahwa konsep cyber notary di Indonesia masih dalam perdebatan, walaupun teknologi memungkinkan peranan Notaris secara online dan remote, namun secara hukum hal tersebut seakan tidak dapat dilakukan (Makarim, 2011:468). Pranata cyber notary, apabila merujuk kepada pendapat para ahli, baik menurut Edmon Makarim maka dalam pendapat keduanya memiliki persamaan yakni, salah satu metode bagi notaris dengan mempergunakan media cyberspace, yang berkaitan dengan tugas dan kewenangan dalam menjalankan jabatannya.

Konsep cyber notary tidak diatur baik dalam tatanan definisi maupun pengaturan atau mekanisme pelaksanaannya. Guna mendapatkan definisi dari cyber notary, Penulis menggunakan metode interpretasi. Metode interpretasi atau penafsiran hukum digunakan karena apabila suatu peristiwa konkret tidak secara jelas dan tegas dianut dalam suatu peraturan perundang-undangan (Mas, 2014:171).

Soeroso menegaskan, bahwa dalam melaksanakan penafsiran peraturan perundangundangan, pertama-tama selalu dilakukan penafsiran grammatikal, karena pada hakikatnya untuk memahami teks peraturan perundang-undangan harus dimengerti terlebih dahulu arti kata-katanya (Soeroso, 2013:99). Perlu diperhatikan bahwasanya frasa cyber notary berada dalam tanda baca kurung. Menurut Kamus Besar Bahasa Indonesia tanda kurung memiliki makna "tanda baca (...) yang mengapit tambahan 
keterangan atau penjelasan". Secara tata bahasa, frasa cyber notary yang terletak dalam tanda baca kurung, merupakan tambahan keterangan atau penjelasan daripada frasa sebelumnya. Sehingga dalam hal ini, cyber notary dalam perspektif interpretasi grammatikal dapat dimaknai secara limitatif terhadap "kewenangan sertifikasi transaksi yang dilakukan secara elektronik".

Ditinjau dari struktur tatanan bahasa, maka kemungkinan pemaknaan terhadap cyber notary dapat mengacu terhadap perbuatan (kewenangan notaris) atau metode pelaksanaan kewenangan tersebut (secara elektronik). Apabila cyber notary merujuk pada pemaknaan grammatikal, yakni terhadap kewenangan sertifikasi transaksi yang dilakukan secara elektronik, maka teranglah bahwa kewenangan tersebut berlaku limitatif hanya terhadap satu kewenangan, yaitu berkenaan dengan sertifikasi transaksi elektronik.

Adapun frasa "secara elektronik" tidak dapat dimaknai sebagai metode pelaksanaan kewenangan, dikarenakan dalam memaknai frasa tersebut, terdapat konjungsi berupa "yang”, sehingga secara elektronik merupakan bagian yang tidak terpisahkan dari "transaksi yang dilakukan secara elektronik". Kaitannya terhadap Teori Kepastian Hukum, salah satu aspeknya adalah terdapat adanya aturan yang bersifat umum membuat individu mengetahui perbuatan apa yang boleh atau tidak boleh dilakukan. Dalam hal ini, agar tercipta dan tercapainya salah satu tujuan hukum, yakni kepastian hukum, diperlukan adanya suatu pemaknaan dalam rumusan cyber notary sebagaimana termaktub dalam UU Jabatan Notaris, guna Notaris dapat mengetahui apakah perbuatan (kewenangan Notaris dalam cyber notary) tersebut boleh dilakukan dan sampai sejauh mana Notaris dapat melaksanakannya, serta mengetahui batasan-batasan pengaplikasian cyber notary dalam rangka pembuatan akta autentik.

Tentang apa yang dimaksud dengan sertifikasi, belum dijumpai adanya pengaturan dan definisi normatif dari sertifikasi, baik itu dalam UU Jabatan Notaris maupun dalam UU ITE. Sehingga dalam memaknai sertifikasi dalam perspektif tatanan bahasa, Penulis menggunakan definisi daripada "sertifikasi" melalui berbagai sumber. Salah satu definisi dari sertifikasi dapat dijumpai pada International Organization for Standardization (selanjutnya disebut "ISO"), yang mengemukakan bahwa sertifikasi (certification) adalah: "Certification - the provision by an independent body of written assurance (a certificate) that the product, service or system in question meets specific requirements".

Sertifikasi merupakan suatu ketetapan tertulis yang dikeluarkan oleh lembaga independen, bahwa produk, layanan, atau sistem tersebut telah memenuhi ketentuan spesifik tertentu. Sertifikasi dalam Kamus Besar Bahasa Indonesia (KBBI) memiliki pemaknaan yang berbeda. Sertifikasi memiliki makna berupa "penyertifikatan". Frasa penyertifikatkan berarti mengacu kepada proses, cara, atau perbuatan. Sehingga sertifikasi merupakan suatu proses, cara, perbuatan menyertifikatkan.

Berdasarkan pemaparan terhadap pemaknaan cyber notary sebagaimana dijabarkan pada pembahasan di atas, maka teranglah konsep cyber notary yang terdapat dalam UU Jabatan Notaris memiliki pemaknaan yang berbeda dari gagasan yang dikemukakan oleh Trade Electronics Data InterCHANGE System Legal Workshop yang diselenggarakan oleh Uni Eropa atau the Information Security Committee of the American Bar Association.

Teori Kepastian Hukum menyatakan bahwa kepastian hukum merupakan adanya aturan yang bersifat umum membuat individu mengetahui perbuatan apa yang boleh atau tidak boleh dilakukan. Dengan berlandaskan kepada Teori Kepastian Hukum, maka pemaknaan terhadap kewenangan Notaris terhadap cyber notary yang semula 
tidak diketahui apakah perbuatan tersebut boleh atau tidak boleh dilakukan yang disebabkan oleh adanya kekosongan hukum (rechtsvacuum), menjadi jelas batasannya, yakni berlaku secara limitatif terhadap sertifikasi transaksi elektronik.

\section{Peluang Penerapan Cyber Notary Dalam Sistem Hukum Di Indonesia}

Seiring dengan perkembangan serta kemajuan teknologi, kewenangan Notaris dalam era digital pun memiliki probabilitas terhadap kewenangannya membuat akta. Salah satunya dapat ditinjau dalam UndangUndang Nomor 40 Tahun 2007 tentang Perseroan Terbatas (selanjutnya disebut "UU PT") yang memberikan kemungkinan untuk dilakukannya Rapat Umum Pemegang Saham (selanjutnya disebut "RUPS") secara remote.

Organ-organ Perseroan Terbatas terdiri dari Rapat Umum Pemegang Saham, Direksi, dan Dewan Komisaris yang di mana ketiga organ tersebut memiliki fungsi, tugas, dan tanggungjawab masing-masing, sebagaimana telah diatur di dalam pasal 1 butir 4, 5, dan 6 Undang-Undang Perseroan Terbatas. Ketiga organ Perseroan tersebut di atas kekuasaan tertinggi ada pada Rapat Umum Pemegang Sama yang di mana RUPS tidak dapat dipisahkan dari perseroan, melalui RUPS, menurut M. Yahya Harahap sebagaimana dikutip oleh Musriansyah, para pemegang saham sebagai pemilik Perseroan melakukan kontrol terhadap kepengurusan yang dilakukan direksi maupun terhadapkekayaan serta kebijakan keengurusanyang dijalankan manajemen perseroan (Musriansyah, 2017:126).

Definisi normatif dari RUPS termaktub dalam pasal 1 angka 4 UU PT, yang berbunyi: "Organ Perseroan yang mempunyai wewenang yang tidak diberikan kepada Direksi atau Dewan Komisaris dalam batas yang ditentukan dalam Undang-Undang ini dan/atau anggaran dasar."

Hasil risalah RUPS merupakan akta Notaris berupa akta pejabat (relaas acten).
Dalam hal pelaksanaan RUPS melalui media telekonferensi, tercantum pada pasal 77 ayat (1) yang berbunyi: "Selain penyelenggaraan RUPS sebagaimana dimaksud dalam Pasal 76 , RUPS dapat juga dilakukan melalui media telekonferensi, video konferensi, atau sarana media elektronik lainnya yang memungkinkan semua peserta RUPS saling melihat dan mendengar secara langsung serta berpartisipasi dalam rapat."

Pada Undang-Undang tersebut dilakukan perubahan atas ketentuan yang menyangkut penyelenggaraan RUPS dengan memanfaatkan perkembangan teknologi. Dengan demikian, penyelenggaraan RUPS dapat dilakukan melalui media elektronik seperti telekonferensi, video konferensi, atau sarana media elektronik lainnya. Ketentuan tersebut dapat dikatakan merupakan salah satu terobosan hukum yang memanfaatkan kemajuan teknologi dalam pengimplementasiannya.

Mekanisme pembuatan akta RUPS secara telekonferensi adalah dimulai dengan Mekanisme pembuatan akta dari hasil Rapat Umum Pemegang Saham yang dilakukan secara telekonferensi terdiri atas pembuatan akta oleh Notaris, kemudian dibacakan secara telekonferensi agar para pihak yang mengikuti RUPS dapat mengetahui isi akta. Setelah para pihak setuju dengan isi akta, kemudian dilakukan penandatanganan akta secara elektronik menggunakan digital signature. Pihak yang menandatangani adalah para pihak peserta RUPS, para saksi, dan Notaris. Semua dilakukan secara digital. Setelah penandatanganan, maka akta RUPS sudah sah dan mengikat para pihak sebagai Undang-undang." (Dewi, 2015:111).

Peluang mengenai konsep cyber notary, walaupun bukan dalam perspektif pembuatan akta, kembali dapat ditinjau dalam hal penyimpanan protokol Notaris. Indah Kusuma Dewi menuturkan bahwa peluang terselenggaranya penyimpanan protokol Notaris dalam bentuk elektronik 
sangat dimungkinkan untuk dilaksanakan, mengingat notaris sudah menerapkan aplikasi elektronik sesuai yang diatur pada : a) Peraturan Menteri Hukum dan Hak Asasi Manusia Republik Indonesia Nomor 4 Tahun 2014 tentang Tata Cara Pengajuan Permohonan Pengesahan Badan Hukum dan Persetujuan Perubahan Anggaran Dasar serta Penyampaian Pemberitahuan Perubahan Anggaran Dasar dan Perubahan Data Perseroan Terbatas; b) Peraturan Menteri Hukum dan HAM Nomor 5 Tahun 2014 tentang Pengesahan Badan Hukum Yayasan; dan c) Peraturan Menteri Hukum dan Hak Asasi Manusia Republik Indonesia Nomor 6 Tahun 2014 tentang pengesahan Badan Hukum Perkumpulan (Dewi, 2015).

Lebih lanjut dijelaskan, bahwasanya membuat pengalihan penyimpanan data secara elektronik hanya dapat berfungsi sebagai back up bukan sebagai salinan yang memiliki kekuatan hukum yang mengikat. Dengan demikian, secara normatif, peluang terhadap pembuatan akta hasil Rapat Umum Pemegang Saham oleh UU PT dan penyimpanan protokol Notaris dalam bentuk elektronik sebenarnya telah terbuka terhadap kemungkinan untuk melakukan pembuatan akta dengan memanfaatkan perkembangan teknologi, namun problematika konsep cyber notary, terdapat dalam kewajiban Notaris dalam pembuatan akta, sebagaimana termaktub dalam pasal 16 ayat (1) huruf $m$ yang menyebutkan bahwa Notaris berkewajban untuk "membacakan Akta di hadapan penghadap dengan dihadiri oleh paling sedikit 2 (dua) orang saksi, atau 4 (empat) orang saksi khusus untuk pembuatan Akta wasiat di bawah tangan, dan ditandatangani pada saat itujuga oleh penghadap, saksi dan Notaris.". Pasal tersebut lebih lanjut diterangkan dalam Penjelasan bahwa Notaris harus hadir secara fisik dan menandatangani Akta di hadapan penghadap dan saksi.

Frasa "secara fisik" inilah yang menyebabkan konsep cyber notary atau pembuatan akta dengan memanfaatkan perkembangan teknologi. Dalam hal ini, dalam hemat Penulis antara kewajiban dan kewenangan Notaris mengalami benturan (conflict of norm). Tidaklah memungkinkan untuk pelaksanaan pembuatan akta yang dalam konsepnya dilaksanakan secara remote dan praktis, untuk kemudian dibebankan kewajiban untuk menghadiri secara fisik. Kewajiban tersebut sejatinya menghilangkan unsur esensial dari konsep cyber notary.

Apabila Notaris tidak melaksanakan kewajiban sebagaimana dimaksud dalam Pasal 16 ayat (1) huruf m, maka kekuatan pembuktian akta Notaris tersebut akan terdegradasi menjadi sebatas akta di bawah tangan. Hal ini sesuai dengan ketentuan Pasal 16 ayat (9) yang berbunyi: "Jika salah satu syarat sebagaimana dimaksud pada ayat (1) huruf $m$ dan ayat (7) tidak dipenuhi, Akta yang bersangkutan hanya mempunyai kekuatan pembuktian sebagai akta di bawah tangan." Dengan demikian, dengan tidak dilaksanakannya kewajiban Notaris tersebut akan mengakibatkan seorang notaris dapat dikenai sanksi perdata. Sanksi ini berupa penggantian biaya, ganti rugi, dan bunga merupakan akibat yang akan diterima Notaris atas tuntutan para penghadap jika akta yang bersangkutan hanya mempunyai kekuatan pembuktian sebagai akta di bawah tangan atau akta menjadi batal demi hukum (Adjie, 2017:93-94).

Berdasarkan kepada pemaparan tersebut, teranglah bahwasanya UU Jabatan Notaris walaupun telah menghadirkan konsep cyber notary dalam kewenangan Notaris, namun pada UU Jabatan notaris masih belum memberikan peluang terhadap penerapan konsep cyber notary di Indonesia. 


\section{SIMPULAN}

1. Konseptualisasi cyber notary dapat diartikan sebagai salah satu metode bagi notaris dengan mempergunakan media cyberspace, yang berkaitan dengan tugas dan kewenangan dalam menjalankan jabatannya, namun dalam UU Jabatan Notaris, kewenangan tersebut berlaku dimaknai secara limitatif terhadap "kewenangan sertifikasi transaksi yang dilakukan secara elektronik".

2. Peluang konsep cyber notary di Indonesia

\section{DAFTAR RUJUKAN}

Adjie, Habib. 2017. Sanksi Perdata dan Administratif Terhadap Notaris Sebagai Pejabat Publik. Bandung. Refika Aditama.

Budhijanto, Danrivanto. 2010. Hukum Telekomunikasi, Penyiaran \& Teknologi Informasi (Regulasi Dan Konvergensi). Refika Aditama. Bandung.

Dewi, Indah Kusuma. 2015. Kajian tentang Penyimpanan Protokol Notaris..., Tesis tidak diterbitkan. Yogyakarta. Fakultas Hukum Universitas Gadjah Mada.

Dewi, Amelia Sri Kusuma. "Penyelenggaraan RUPS Melalui Media Elektronik T..." (online), Arena Hukum, Vol 8, No 1 (2015), hlm. 111, diakses pada 20 Maret 2018. Sumber. doi: https://doi.org/10.21776/ ub.arenahukum.2015.00801.7.

Edmon Makarim. "Modernisasi Hukum Notaris Masa Depan: Kajian Hukum Terhadap Kemungkinan ...". Jurnal Hukum dan Pembangunan. Vol. telah dimungkinkan dalam hal pembuatan akta hasil Rapat Umum Pemegang Saham (RUPS) dan penyimpanan protokol Notaris dalam bentuk elektronik, namun dalam UU Jabatan Notaris masih belum membuka peluang terhadap kemungkinan dilakukannya konsep cyber notary karena terkendala oleh kewajiban Notaris sebagaimana termaktub dalam Pasal 16 ayat (1) huruf m UU Jabatan Notaris.

41, No. 3 (2011), diakses pada 15 Desember 2017. Sumber. doi: http:// dx.doi.org/10.21143/jhp.vol41.no3.287.

Mas, Marwan. 2014. Pengantar Ilmu Hukum. Bogor. Penerbit Ghalia Indonesia.

Musriansyah, Sihabudin. "Perlindungan Hukum Terhadap Pemegang Saham Dalam Penjualan Aset Perseroan Berdasarkan Pasal 102 Ayat (4) UU Nomor 40 Th.2007 Tentang Perseroan Terbatas". JIPPK. Vol. 2, No, 2 (2017), diakses pada 30 Mei 2018 Sumber. doi: http://dx.doi. org/10.17977/um019v2i22017p125.

Nurita, R. A. Emma. 2012. CYBER NOTARY (Pemahaman Awal d...). Bandung. Refika Aditama.

Smith, Leslie G. 2006. The Role of The Notary in Secure Electronic Commerce. Information Security Institute Faculty of Information Technology. Queensland University of Technology.

Soeroso. 2013. Pengantar Ilmu Hukum. Jakarta. Sinar Grafika. 